\title{
RESPONS SAWI (Brassica juncea L. Czern) YANG DIBUDIDAYAKAN SECARA HIDROPONIK PADA MEDIA PADAT DAN CAIR TERHADAP KONSENTRASI NITROGEN
}

\author{
Nanang Setiawan, Yohannes Cahya Ginting \& Agus Karyanto \\ Jurusan Agroteknologi, Fakultas Pertanian Universitas Lampung \\ Jl. Prof. Soemantri Brodjonegoro, No. 1, Bandar Lampung 35145 \\ E-mail: Nanangstone@yahoo.co.id
}

\begin{abstract}
ABSTRAK
Sawi merupakan salah satu sayuran berumur pendek dan sangat digemari seluruh lapisan masyarakat. Sawi dapat tumbuh pada pada berbagai jenis tanah dan dapat ditumbuhkan secara hidroponik. Penelitian ini bertujuan untuk mengetahui respons tanaman sawi terhadap perbedaan konsentrasi nitrogen $(\mathrm{N})$ dalam meningkatkan pertumbuhan dan hasil tanaman sawi, mengetahui respons pertumbuhan dan hasil tanaman sawi pada media tanam yang berbeda antara media cair dan media padat, dan mengetahui pengaruh interaksi antara media tanam yang digunakan dan konsentrasi nitrogen (N) yang diberikan pada pertumbuhan dan hasil tanaman sawi. Penelitian ini dilaksanakan di Rumah Kaca Fakultas Pertanian Universitas Lampung pada bulan September - November 2012. Penelitian ini menggunakan Rancangan Acak Kelompok (RAK) pola Faktorial yang terdiri dari dua faktor. Faktor pertama adalah perlakuan konsentrasi nitrogen $(\mathrm{N})$ yaitu: $\mathrm{N}_{1}=150 \mathrm{ppm}, \mathrm{N}_{2}=175 \mathrm{ppm}, \mathrm{N}_{3}=200 \mathrm{ppm}$, $\mathrm{N}_{4}=225 \mathrm{ppm}$, dan $\mathrm{N}_{5}=250 \mathrm{ppm}$. Faktor kedua adalah perlakuan media tanam $(\mathrm{M})$, yaitu $\mathrm{M}_{1}=$ campuran pasir dengan arang sekam (1:1) dan $\mathbf{M}_{2}=$ air. Homogenitas ragam diuji dengan uji Bartlett dan kemenambahan data diuji dengan uji Tukey. Jika asumsi terpenuhi, data dianalisis ragam dan dilanjutkan dengan uji ortogonal kontras pada taraf $5 \%$. Hasil penelitian menunjukkanbahwa pertumbuhan tanaman sawi pada media cair tidak normal di duga disebabkan oleh faktor pembatas oksigen dan pengendapan. Sementara itu respons tanaman sawi pada konsentrasi nitrogen sampai 250 ppm pada media padat responsnya menurun. Setiap penambahan konsentrasi nitrogen 10 ppm terjadi penurunan tinggi tanaman, bobot basah tajuk, bobot basah akar, jumlah daun, bobot kering tajuk, dan bobot kering akar dengan nilai masing-masing sebesar $0,60 \mathrm{~cm}, 0,20 \mathrm{helai}, 2,00 \mathrm{~g}, 0,30 \mathrm{~g}$, $0,30,0,10 \mathrm{~g}$, dan $0,80 \mathrm{~g}$.
\end{abstract}

Kata kunci : Dosis pupuk nitrogen, hidroponik, media tanam, dan sawi.

\section{PENDAHULUAN}

Tingkat konsumsi sayuran rakyat Indonesia saat ini masih rendah, hanya $35 \mathrm{~kg}$ sayuran per kapita per tahun. Angka itu jauh lebih rendah dari angka konsumsi sayuran yang dianjurkan organisasi pangan dan pertanian dunia (Food and Agriculture Organization), yaitu 75 kg per kapita per tahun (Republika Online, 2010).

Salah satu sayuran yang dapat diproduksi dengan cepat dan sangat potensial untuk dikomersialkan adalah sawi (Brassica juncea (L.) Czern). Sawi dapat tumbuh pada pada berbagai jenis tanah dan dapat ditumbuhkan secara hidroponik. Dengan demikian, sawi cocok untuk dikembangkan di daerah perkotaan yang areal lahan pertaniannya semakin terbatas dengan sistem hidroponik.

Sistem hidroponik dapat memberikan sistem budidaya yang lebih terkontrol. Dengan pengembangan teknologi, kombinasi sistem hidroponik dengan membran mampu mendayagunakan air nutrisi, pestisida secara nyata lebih efisien (minimalis system) dibandingkan dengan kultur tanah (terutama tanaman berumur pendek) (Lonardy (2006), yang dikutip oleh Hidayat (2009).
Semua keuntungan yang diperoleh melalui teknik budidaya hidroponik sangat ditentukan oleh komposisi kandungan unsur hara makro maupun mikro. Salah satu unsur hara yang banyak dibutuhkan oleh tanaman sayuran daun adalah unsur nitrogen $(\mathrm{N})$. Unsur $\mathrm{N}$ berperan pembentukan asam amino untuk pembentukan protein dan akan mempengaruhi pembentukan klorofil. Jumlah klorofil dari tanaman akan berpengaruh juga pada proses fotosintesis. Hasil fotosintesis berupa karbohidrat tidak dapat diubah menjadi protein apabila $\mathrm{N}$ yang ada dalam tanaman tidak memadai.

Konsentrasi nitrogen untuk pembuatan larutan nutrisi hidroponik harus sesuai dengan kebutuhan tanaman, karena pemberian nitrogen yang terlalu banyak pada tanaman dapat mengakibatkan warna daun menjadi lebih tua, tanaman menjadi lemah, sehingga tanaman mudah terserang hama dan penyakit. Sebaliknya jika tanaman kekurangan unsur nitrogen,maka pertumbuhan terhambat sehingga tanaman sawi tampak kurus, dan kerdil, pembentukan klorofil terhambat sehingga laju fotosintesis terganggu, pembentukan akar berkurang, dan daun tampak menguning (Nyakpa, 1988). 
Media tanam dalam hidroponik berperan sebagai penopang tumbuh dan sarana penyedia unsur hara bagi tanaman, dan dalam hal ini media tumbuh yang dapat digunakan dalam budidaya hidroponik harus dapat mendukung pertumbuhan dan perkembangan tanaman, mempunyai aerasi yang baik, serta dapat menjaga ketersediaan air bagi tanaman.

Media padat yang digunakan sebagai media dalam penelitian ini berupa campuran pasir dan arang sekam, dimana kita ketahui bahwa pasir mempunyai porositas dan berat yang baik sehingga dapat menjaga aerasi dan dapat mendukung tegaknya tanaman (Anonim, 2011). Ditambah lagi dengan penggunaan arang sekam yang dapat menyimpan air dengan baik. Oleh karenanya, dengan penggunaan media padat yang dipadukan dengan pemberian dosis $\mathrm{N}$ yang tepat diharapakan dapat menghasilkan pertumbuhan dan hasil sawi yang sama baiknya dengan budidaya hidroponik dengan media cair.

\section{BAHAN DAN METODE}

Penelitian ini dilaksanakan di Rumah Kaca Fakultas Pertanian Universitas Lampung pada bulan September-November 2012. Bahan yang digunakan adalah arang sekam, pasir, kertas label, pupuk NPK mutiara, urea, kalsium klorida, magnesium sulfat, besi sulfat, mangan sulfat, asam boraks, tembaga sulfat, seng sulfat, natrium molibad, baskom, aquades dan benih sawi varietas lokal.

Penelitian ini menggunakan Rancangan Acak Kelompok (RAK) pola Faktorial yang terdiri dari 2 faktor. Faktor pertama adalah perlakuan konsentrasi nitrogen (N) yaitu : $\mathrm{N}_{1}=150 \mathrm{ppm}, \mathrm{N}_{2}=175 \mathrm{ppm}, \mathrm{N}_{3}=200 \mathrm{ppm}$, $\mathrm{N}_{4}=225 \mathrm{ppm}$, dan $\mathrm{N}_{5}=250 \mathrm{ppm}$. Faktor kedua adalah perlakuan media tanam (M), yaitu $\mathrm{M}_{1}=$ campuran pasir dengan arang sekam (1:1) dan $\mathbf{M}_{2}=$ air. Homogenitas ragam diuji dengan uji Bartlett dan kemenambahan data diuji dengan uji Tukey. Jika asumsi terpenuhi, data dianalisis ragam dan dilanjutkan dengan uji ortogonal kontras pada taraf $5 \%$. Peubah yang diamati adalah tinggi tanaman, jumlah daun, bobot basah tajuk, bobot basah akar, luas daun, bobot kering tajuk, dan bobot kering akar.

\section{HASIL DAN PEMBAHASAN}

Pengaruh media tanam berbeda untuk semua variabel pengamatan. Media padat $\left(\mathrm{M}_{1}\right)$ lebih baik dibandingkan dengan media cair $\left(\mathrm{N}_{2}\right)$ pada variabel tinggi tanaman, bobot basah tajuk, bobot basah akar, jumlah daun, bobot kering tajuk, dan bobot kering akar dengan selisih masing-masing sebesar 239,16 cm, 276,67 helai,
$1291,10 \mathrm{~g}, 262,23 \mathrm{~g}, 444,91 \mathrm{~cm}^{2}, 430,07 \mathrm{~g}$, dan $503,42 \mathrm{~g}$. Pengaruh dosis pupuk NPK berbeda pada semua variabel pengamatan, kecuali bobot kering akar. Pengaruh interaksi antara media tanam dan dosis pupuk nitrogen berbeda di semua variabel pengamatan, kecuali variabel tinggi tanaman dan jumlah daun (Tabel 1).

Hasil penelitian menunjukkan bahwa pertumbuhan tanaman sawi pada media padat jauh lebih baik dibandingkan tanaman sawi pada media cair. Respons tanaman sawi ini terhadap media tumbuh yang diuji konsisten untuk semua variabel pengamatan yaitu tinggi tanaman, jumlah daun, bobot basah tajuk, bobot basah akar, luas daun, bobot kering tajuk, dan bobot kering akar. pertumbuhan tanaman sawi pada media cair tidak normal. Hal ini diduga karena pada sistem media cair mengapung (Floating Hidroponic Sistem/FHS) merupakan suatu budidaya tanaman khususnya sayuran dengan cara menanamkan tanaman pada lubang styrofoam yang mengapung diatas permukaaan larutan nutrisi dalam suatu bak penampung atau kolam sehingga akar tanaman terapung atau terendam dalam larutan nutrisi. Dalam penelitian ini larutan nutrisi tidak disirkulasikan dan tidak dilakukan pengontrolan kepekatan larutan dalam jangka waktu yang cukup lama sehingga terjadi pengkristalan dan pengendapan nutrisi dalam dasar kolam yang dapat mengganggu pertumbuhan tanaman. Sedangkan pada media padat, larutan hara yang diberikan dapat langsung diserap oleh perakaran tanaman sawi.

Tumbuhan juga menyerap $\mathrm{O}_{2}$ untuk pernafasannya, umumnya diserap melalui daun (stomata). Pada keadaan aerob, tumbuhan melakukan respirasi aerob. Bila dalam keadaan anaerob atau kurang oksigen, jaringan melakukan respirasi secara anaerob. Misal pada akar yang tergenang air. Pada respirasi aerob terjadi pembakaran (oksidasi) zat gula (glukosa) secara sempurna, sehingga menghasilkan energi jauh lebih besar daripada respirasi anaerob (Suyitno, 2006). Pada penelitian ini pemberian $\mathrm{O}_{2}$ kurang maksimal sehingga pertumbuhan pada media cair terhambat. Ini diduga karena penurunan oksigen karena suhu yang relatif tinggi

Menurut Morgan (2000) saat suhu tinggi jumlah oksigen yang terkandung dalam larutan hara akan menurun cepat. Suhu tinggi dapat meningkatkan laju respirasi dari akar sehingga proses respirasi akan berlipat ganda untuk setiap kenaikan $10^{\circ} \mathrm{C}$ sampai batas $30^{\circ} \mathrm{C}$. Pada saat keperluan oksigen berlipat ganda tetapi kapasitas oksigen yang dapat dibawa dari larutan menurun menyebabkan oksigen yang larut akan lebih cepat berkurang di dalam larutan dan untuk suatu periode tanaman dapat menderita karena kekurangan oksigen. Kemungkinan lain, media cair yang menggenang dan 
Tabel 1. Pengaruh media tanam dan dosis pupuk nitrogen $(\mathrm{N})$ pada pertumbuhan dan hasil sawi

\begin{tabular}{|c|c|c|c|c|c|c|c|}
\hline \multirow{2}{*}{ Perbandingan } & TT & JD & BB T & BBA & LD & $\mathrm{BKT}$ & BKA \\
\hline & \multicolumn{7}{|c|}{ - - - (F-Hit dan angka dalam kurung merupakan selisih (\%)) - - - } \\
\hline \multicolumn{8}{|l|}{ Media Tanam (m) } \\
\hline $\mathrm{C} 1: \mathrm{m}_{1}$ vs $\mathrm{m}_{2}$ & $\begin{array}{l}259,55^{*} \\
(239,16) \\
\end{array}$ & $\begin{array}{l}188,12 * \\
(276,67) \\
\end{array}$ & $\begin{array}{l}509,92^{*} \\
(1291,10)\end{array}$ & $\begin{array}{l}80,64 * \\
(262,23) \\
\end{array}$ & $\begin{array}{l}529,81^{*} \\
(444,91) \\
\end{array}$ & $\begin{array}{l}266,64^{*} \\
(430,07) \\
\end{array}$ & $\begin{array}{l}112,95^{*} \\
(503,42) \\
\end{array}$ \\
\hline \multicolumn{8}{|l|}{ Dosis pupuk $(\mathrm{N})$} \\
\hline C2 : N Linear & $13,39^{*}$ & $6,31^{*}$ & $17,59^{*}$ & $10,04^{*}$ & $12,49^{*}$ & $16,40^{*}$ & $3,54^{\text {tn }}$ \\
\hline C3: N Kuadratik & $2,57^{\operatorname{tn}}$ & $0,03^{\mathrm{tn}}$ & $3,33^{\operatorname{tn}}$ & $0,28^{\mathrm{n}}$ & $0,20^{\mathrm{tn}}$ & $3,16^{\mathrm{tn}}$ & $2,43^{\text {tn }}$ \\
\hline \multicolumn{8}{|l|}{ Interaksi } \\
\hline $\mathrm{C} 4: \mathrm{C} 1 \times \mathrm{C} 2$ & $0,15^{\mathrm{tn}}$ & $0,07^{\mathrm{tn}}$ & $7,72 *$ & $17,34^{*}$ & $11,41^{*}$ & $18,79^{*}$ & $13,63^{*}$ \\
\hline $\mathrm{C} 5: \mathrm{C} 1 \times \mathrm{C} 3$ & $0,14^{\text {tn }}$ & $0,44^{\mathrm{tn}}$ & $0,26^{\mathrm{tn}}$ & $0,03^{\operatorname{tn}}$ & $2,29^{\text {tn }}$ & $1,78^{\text {th }}$ & $3,95^{\text {th }}$ \\
\hline \multicolumn{8}{|c|}{ Tanggapan terhadap M pada } \\
\hline $\mathrm{n}_{1}: \mathrm{m}_{1}$ vs $\mathrm{m}_{2}$ & - & - & $\begin{array}{l}131,14^{*} \\
(1536,07)\end{array}$ & $\begin{array}{l}46,33^{*} \\
(650,87)\end{array}$ & $\begin{array}{l}145,92^{*} \\
(535,29)\end{array}$ & $\begin{array}{l}85,62^{*} \\
(660,11)\end{array}$ & $\begin{array}{l}37,55^{*} \\
(1113,87)\end{array}$ \\
\hline $\mathrm{n}_{2}: \mathrm{m}_{1} \mathrm{vs} \mathrm{m}_{2}$ & - & - & $\begin{array}{l}125,95^{*} \\
(1197,22)\end{array}$ & $\begin{array}{l}22,76^{*} \\
(278,70)\end{array}$ & $\begin{array}{l}114,81^{*} \\
(420,87)\end{array}$ & $\begin{array}{l}84,23^{*} \\
(460,04)\end{array}$ & $\begin{array}{l}38,24^{*} \\
(766,15)\end{array}$ \\
\hline $\mathrm{n}_{3}: \mathrm{m}_{1}$ vs $\mathrm{m}_{2}$ & - & - & $\begin{array}{l}117,38^{*} \\
(1634,15) \\
74,45^{*}\end{array}$ & $\begin{array}{l}19,89^{*} \\
(317,26) \\
8,23^{*}\end{array}$ & $\begin{array}{l}132,30^{*} \\
(689,60) \\
103,01^{*}\end{array}$ & $\begin{array}{l}64,71^{*} \\
(539,44) \\
37,22^{*}\end{array}$ & $\begin{array}{l}36,09^{*} \\
(845,57) \\
17,03^{*}\end{array}$ \\
\hline $\mathrm{n}_{4}: \mathrm{m}_{1} \mathrm{vs} \mathrm{m}_{2}$ & - & - & $(800,67)$ & $(156,99)$ & $(404,02)$ & $(312,11)$ & $(338,22)$ \\
\hline $\mathrm{n}_{5}: \mathrm{m}_{1} \mathrm{vs} \mathrm{m}_{2}$ & - & - & $\begin{array}{l}69,82^{*} \\
(1793,88)\end{array}$ & $\begin{array}{l}1,38^{\mathrm{tn}} \\
(54,15)\end{array}$ & $\begin{array}{l}49,32^{*} \\
(260,96)\end{array}$ & $\begin{array}{l}15,50 * \\
(238,99)\end{array}$ & $\begin{array}{l}1,74^{\mathrm{tn}} \\
(76,59)\end{array}$ \\
\hline \multicolumn{8}{|c|}{ Tang gapan terhadap $\mathrm{N}$ pada } \\
\hline $\mathrm{m}_{1}: \mathrm{N}$ Linear & - & - & $24,30 *$ & $26,88 *$ & $23,88^{*}$ & $35,16^{*}$ & $15,53^{*}$ \\
\hline $\mathrm{m}_{1}: \mathrm{N}$ Kuadratik & - & - & $2,72 \mathrm{tn}$ & $0,24 \mathrm{tn}$ & $1,92 \mathrm{tn}$ & $4,84 *$ & $6,28 *$ \\
\hline $\mathrm{m}_{2}: \mathrm{N}$ Linear & - & - & $1,00 \mathrm{tn}$ & $0,50 \mathrm{tn}$ & $0,01 \mathrm{tn}$ & 0,04 tn & $1,64 \mathrm{tn}$ \\
\hline $\mathrm{m}_{2}: \mathrm{N}$ Kuadratik & - & - & $0,86 \mathrm{tn}$ & $0,07 \mathrm{tn}$ & $0,57 \mathrm{tn}$ & 0,10 tn & $0,09 \mathrm{tn}$ \\
\hline
\end{tabular}

Keterangan:

F-tabel $0,05=4,41 . \mathrm{tn}=$ tidak nyata, $*=$ nyata pada $\alpha_{0,05}, * *=$ nyata pada $\alpha_{0,01} \cdot \mathrm{M}_{1}=$ campuran media pasir dan arang sekam (1:1), $\mathrm{M}_{2}=$ media cair. $\mathrm{TT}=$ Tinggi tanaman, $\mathrm{JD}=$ Jumlah daun, $\mathrm{BBT}=\mathrm{Bobot}$ basah tajuk, $\mathrm{BBA}=$ Bobot basah akar, $\mathrm{LD}=$ Luas daun, $\mathrm{BKT}=$ Bobot kering tajuk, dan $\mathrm{BKA}=$ Bobot kering akar.

lebih dominan diam menyebabkan unsur hara yang relatif bersifat immobile seperti $\mathrm{P}, \mathrm{Cu}$, dan Zn (Dueck $d k k$ (1986); Burkert dan Robson (1994) yang dikutip oleh Jones (2005) mengendap sehingga terjadi ketidakseimbangan unsur hara yang diserap tanaman. Sedangkan pada media padat, semua larutan hara terjerap dalam media padat sehinngga unsur-unsur hara yang diberikan dapat diserap oleh tanaman melalui mekanisme penyerapan hara akar tanaman seperti aliran massa, intersepsi akar, dan difusi.

Respons pertumbuhan dan hasil tanaman sawi menurun seiring dengan peningkatan konsentrasi nitrogen yang diberikan hingga 250 ppm pada media padat berdasarkan semua variabel yang diamati (Gambar 1 dan 2). Hal ini diduga pada konsentrasi nitrogen sebesar 150 ppm sudah memberikan respons pertumbuhan dan hasil sawi maksimum, sehingga peningkatan unsur hara yang berlebih justru dapat menghambat pertumbuhan dan hasil tanaman sawi. Menurut Jones (2005) konsentrasi nitrogen yang dianjurkan untuk sayuran hidroponik berkisar antara 110-200 ppm, dan konsentrasi 150 yang merupakan konsentrasi terbaik dalam penelitian ini sudah masuk dalam kisaran konsentrasi yang dianjurkan.

Permasalahan utama dalam FSH adalah terendamnya akar tanamandalam larutan hara. Hal ini mengakibatkan rendahnya kadar oksigen di zona perakaran. Morard and Silvestre (1996, dalam Susila, 2009) menyatakan bahwa ruang pori yang berisi air dapat memperlambat atau bahkan memutuskan pertukaran gas antara atmosfer dan rizosfer akibatnya konsentrasi oksigen yang diperlukan untuk respirasi akar menjadi faktor pembatas. Kekurangan oksigen pada aktifitas sistem perakaran mempengaruhi terjadinya proses penyerapan air dan mineral hara.

Menurut Drewand Stolzy (1991) dalam Susila (2009) gangguan akar sebagai akibat kekurangan oksigen (deoksigenasi) adalah pertumbuhan dan perkembangan 


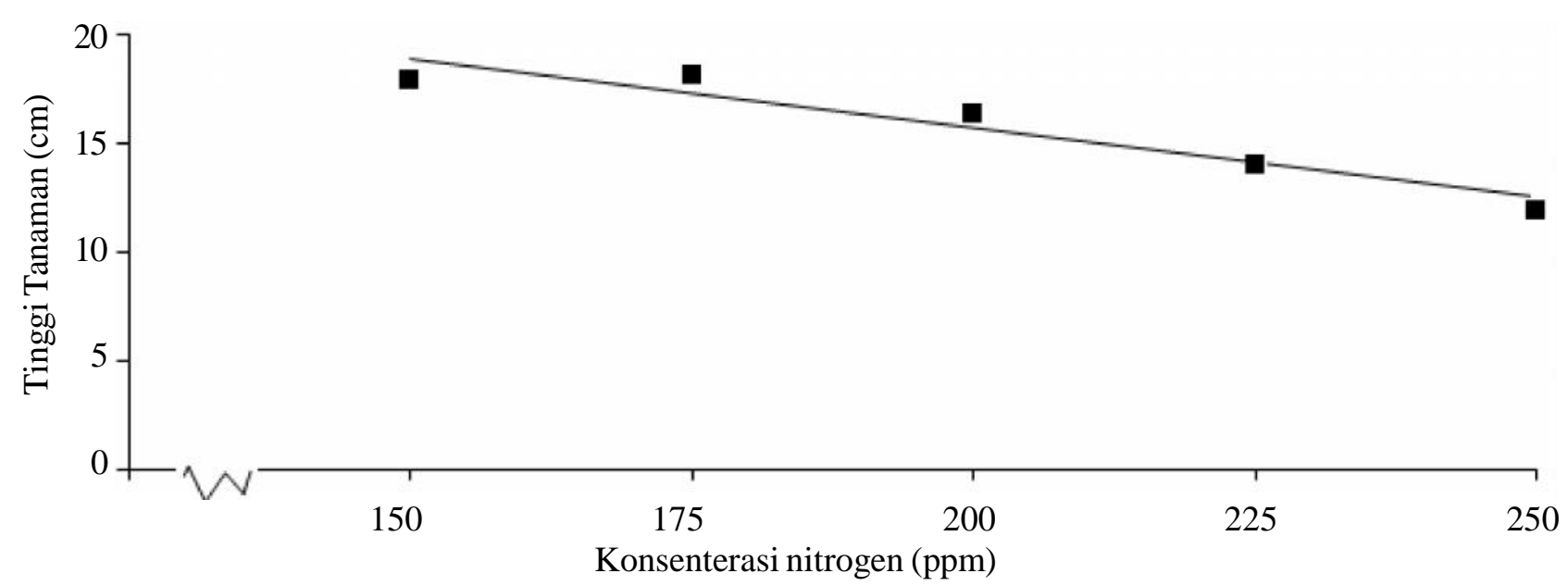

Gambar 1(a). Hubungan antara dosis nitrogen dengan pertumbuhan dan hasil sawi pada variabel tinggi tanaman. $\hat{\mathrm{y}}=-0,06 \mathrm{x}+27,74 \cdot \mathrm{r}=0,91^{*}$.

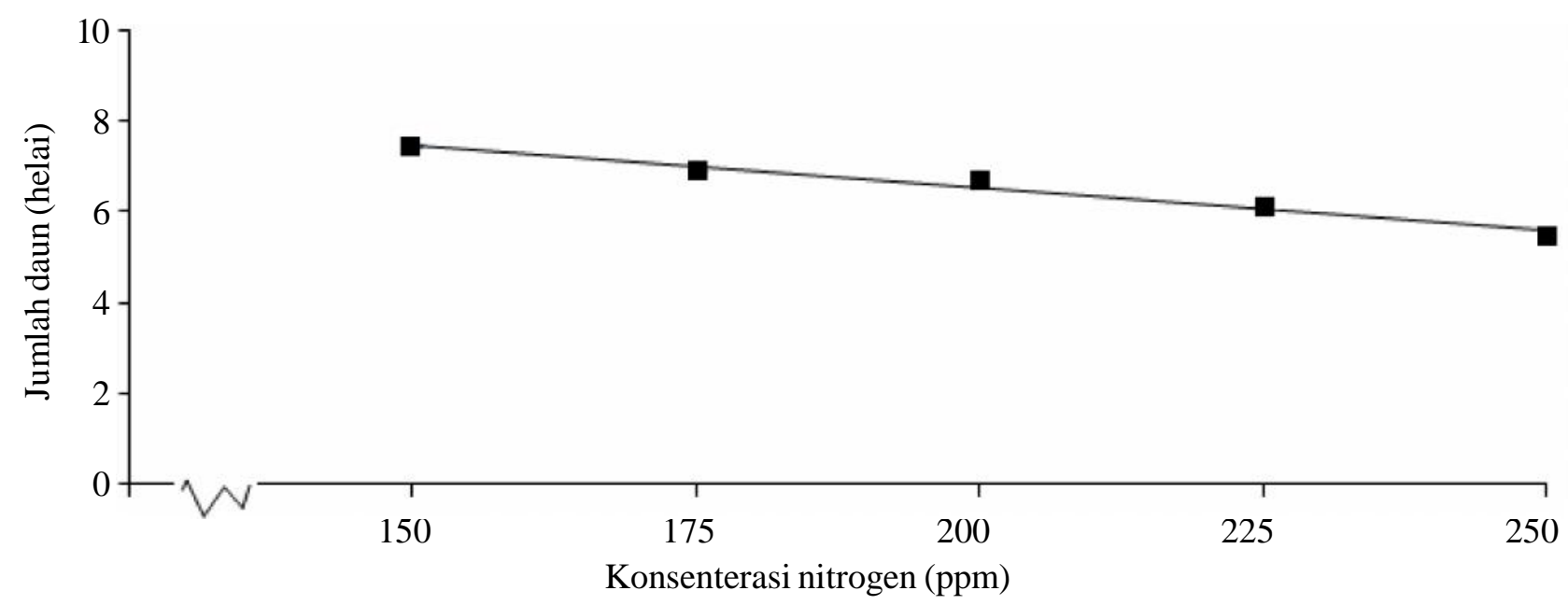

Gambar 1(b). Hubungan antara dosis nitrogen dengan pertumbuhan dan hasil sawi pada variabel jumlah daun. $\hat{\mathrm{y}}=-0,02+10,17 \cdot \mathrm{r}=0,98^{*}$

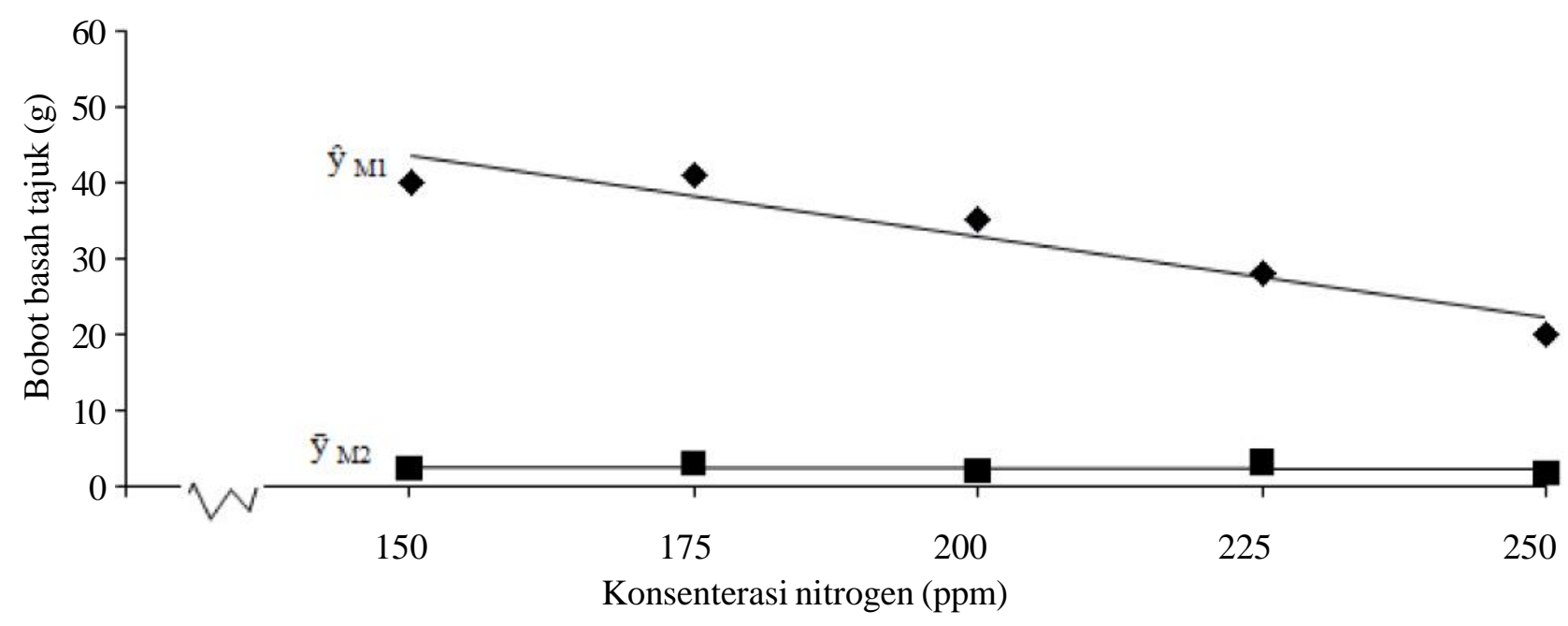

Gambar 2(a). Hubungan interaksi antara dosis nitrogen dan media tanam dengan pertumbuhan dan hasil sawi pada variabel bobot basah tajuk. $\hat{\mathrm{y}}_{\mathrm{M} 1}=-0,02 \mathrm{x}+72,01 ; \mathrm{r}=0,95^{*} \cdot \overline{\mathrm{y}}_{\mathrm{M} 2}=2,34$. 


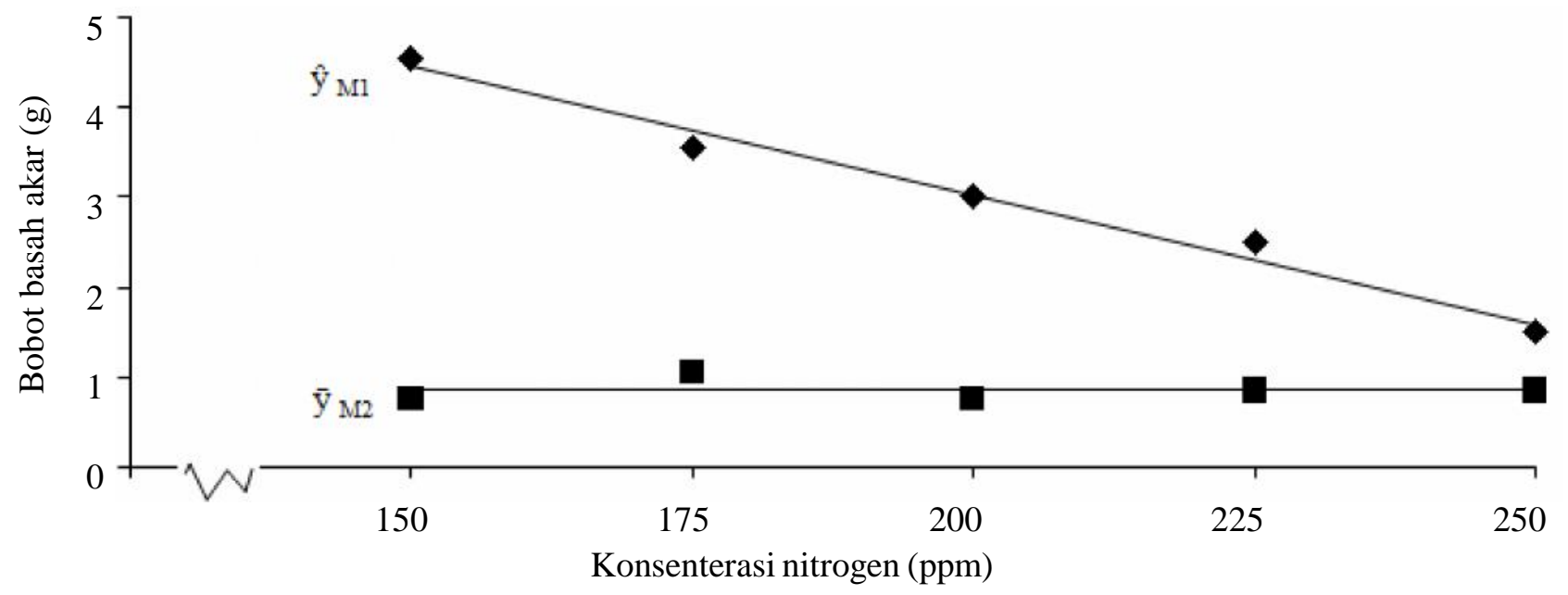

Gambar 2(b). Hubungan interaksi antara dosis nitrogen dan media tanam dengan pertumbuhan dan hasil sawi pada variabel bobot basah akar. $\hat{\mathrm{y}}_{\mathrm{M} 1}=-0,03 \mathrm{x}+9,31 ; \mathrm{r}=0,99^{*} \cdot \overline{\mathrm{y}}_{\mathrm{M} 2}=0,85$.

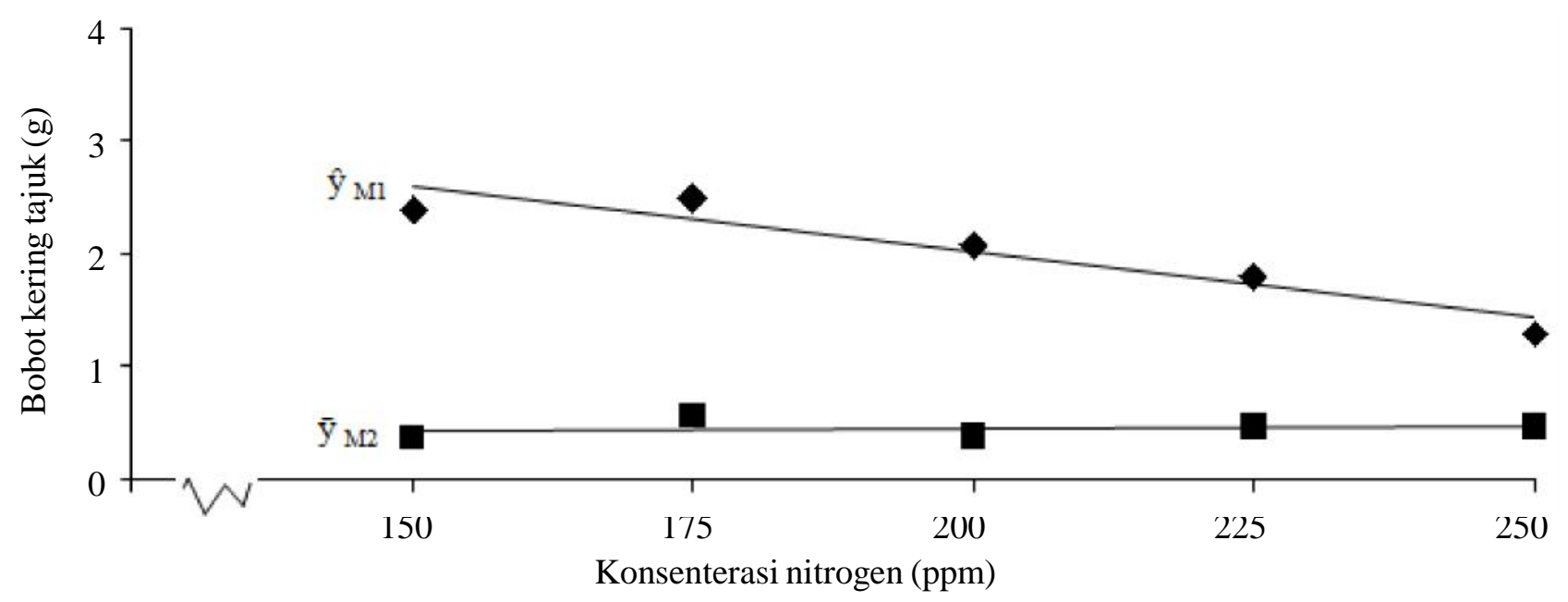

Gambar 2(c). Hubungan interaksi antara dosis nitrogen dan media tanam dengan pertumbuhan dan hasil sawi pada variabel bobot kering tajuk. $\hat{\mathrm{y}}_{\mathrm{M} 1}=-0,01 \mathrm{x}+4,32 ; \mathrm{r}=0,93^{*} \cdot \overline{\mathrm{y}}_{\mathrm{M} 2}=0,37$.

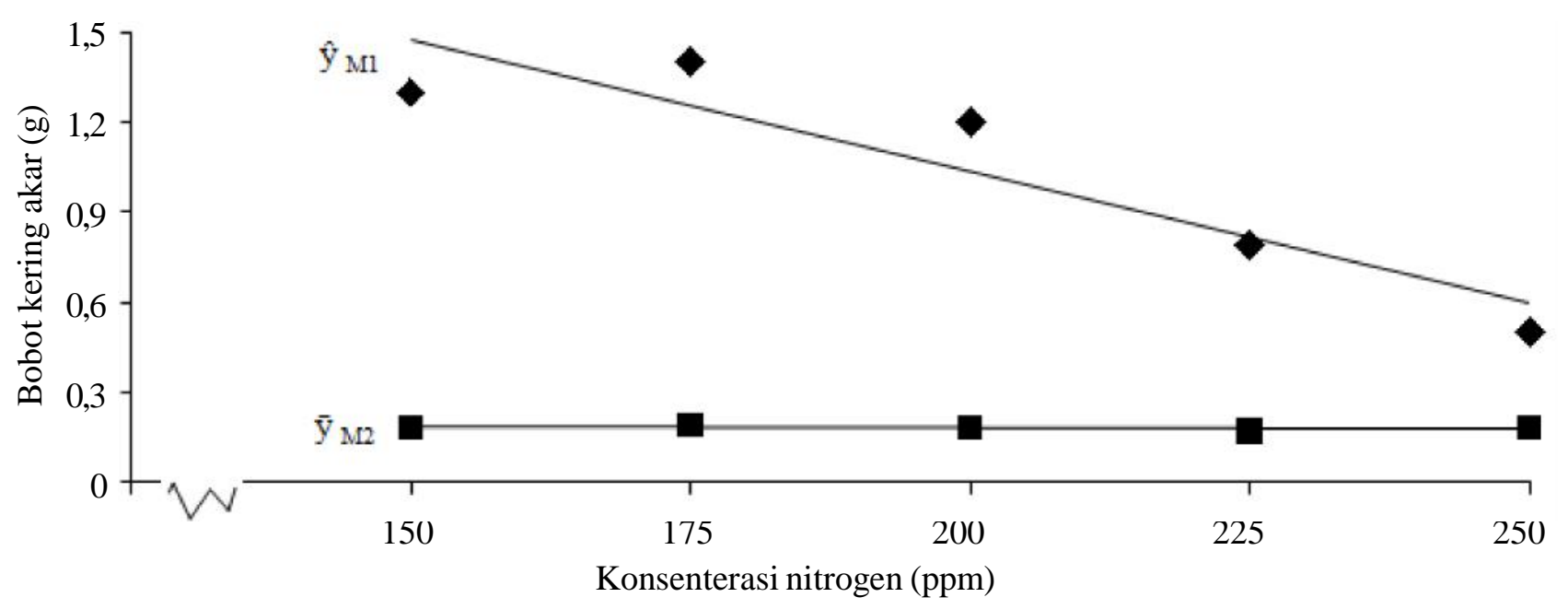

Gambar 2(d). Hubungan interaksi antara dosis nitrogen dan media tanam dengan pertumbuhan dan hasil sawi pada variabel bobot kering akar. $\hat{\mathrm{y}}_{\mathrm{M} 1}=-0,0081 \mathrm{x}+2,70 ; \mathrm{r}=0,88^{*} \cdot \overline{\mathrm{y}}_{\mathrm{M} 2}=0,8$. 


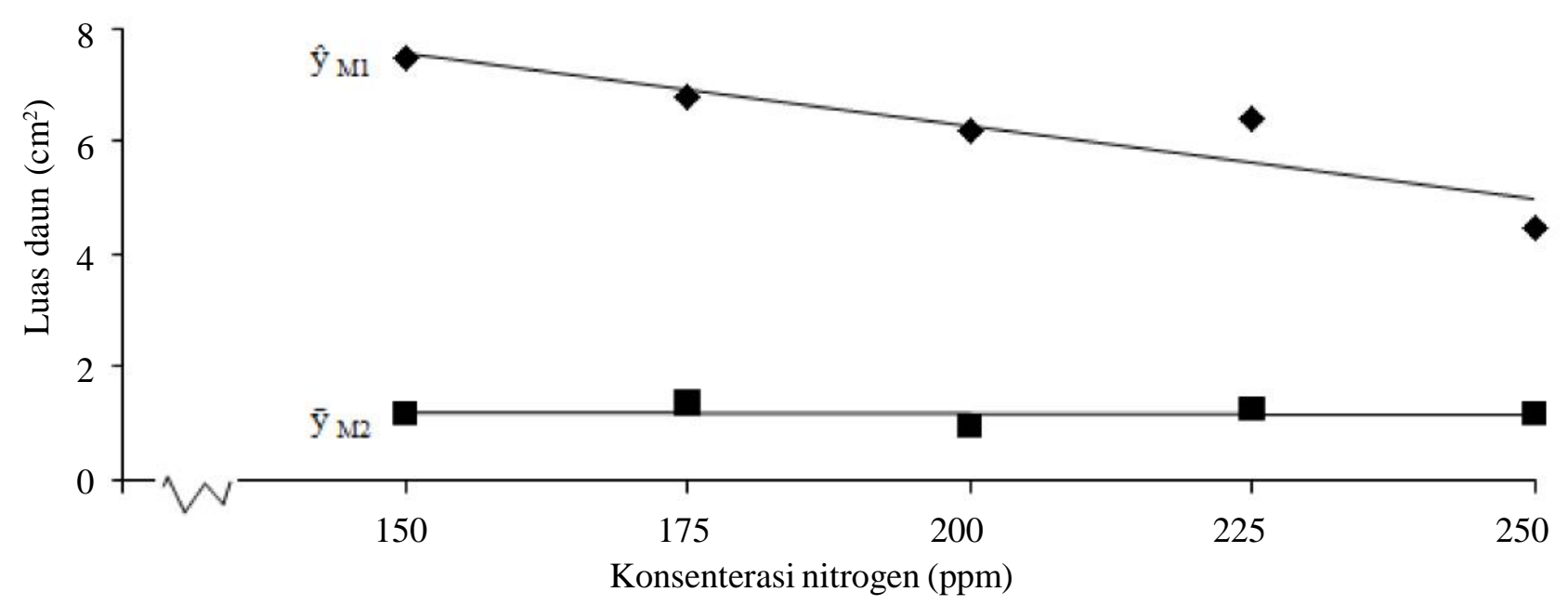

Gambar 2(e). Hubungan interaksi antara dosis nitrogen dan media tanam dengan pertumbuhan dan hasil sawi pada variabel luas daun. $\hat{\mathrm{y}}_{\mathrm{M} 1}=-0,03 \mathrm{x}+12,01 ; \mathrm{r}=0,91 * \overline{\mathrm{y}}_{\mathrm{M} 2}=1,17$.

tanaman yang tidak sempurna serta menurunnya hasil panen.

Hal ini dapat dilihat dari semua variabel pengamatan yang menunjukkan bahwa tanaman sawi memberikan respons linier menurun terhadap peningkatan konsentrasi nitrogen dari 150-250 ppm. Setiap peningkatkan $1 \mathrm{ppm}$ nitrogen pada media padat akan menurunkan tinggi tanaman, bobot basah tajuk, bobot basah akar, jumlah daun, bobot kering tajuk, dan bobot kering akar dengan nilai masing-masing sebesar $0,06 \mathrm{~cm}, 0,02$ helai, $0,20 \mathrm{~g}, 0,03 \mathrm{~g}, 0,03,0,01 \mathrm{~g}$, dan 00,8 $\mathrm{g}$ (Gambar 1 dan 2). Pernyataan ini didukung oleh Russel (1950) dalam Sukantana (1990) yang dikutip oleh Nathania $d k k$ (2012) yang menyatakan bahwa terdapat hubungan yang linier antara tekanan osmosis dan hasil. Semakin tinggi tekanan osmosis di sekitar perakaran tanaman, maka semakin rendah hasil sawi yang didapatkan.

Interaksi antara konsentrasi nitrogen dengan media tanam yang digunakan berpengaruh pada semua variabel pengamatan kecuali variabel tinggi tanaman dan jumlah daun. Dalam interaksi yang terjadi, diketahui bahwa respons tanaman sawi terhadap media padat pada semua konsentrasi nitrogen yang diaplikasikan lebih baik dibandingkan dengan media cair.

Respons tanaman sawi terhadap konsentrasi nitrogen pada media padat menunjukkan respons liniear menurun untuk variabel bobot basah tajuk, bobot basah akar, luas daun, bobot kering tajuk, dan bobot kering akar. Sedangkan respons tanaman sawi terhadap konsentrasi nitrogen pada media cair tidak berbeda untuk semua variabel pengamatan (Tabel 1). Hal ini memperkuat pernyataan sebelumnya bahwa larutan hara yang diberikan pada media padat lebih efektif dan effisien diserap oleh tanaman dibandingkan hara yang dilarutkan pada media cair.

\section{KESIMPULAN}

Berdasarkan hasil penelitian, maka dapat disimpulkan bahwa pertumbuhan tanaman sawi pada media cair tidak normal di duga disebabkan oleh faktor pembatas oksigen dan pengendapan. Sementara itu respons tanaman sawi pada konsentrasi nitrogen sampai $250 \mathrm{ppm}$ pada media padat responsnya menurun. Setiap penambahan konsentrasi nitrogen $10 \mathrm{ppm}$ terjadi penurunan tinggi tanaman, bobot basah tajuk, bobot basah akar, jumlah daun, bobot kering tajuk, dan bobot kering akar dengan nilai masing-masing sebesar $0,60 \mathrm{~cm}, 0,20$ helai, 2,00 g, 0, 30 g, 0,30, 0,10 g dan 0,80 g.

\section{DAFTAR PUSTAKA}

Anonim. 2011. Hidroponik. http://hijaunya. wordpress.com/2011/06/12/hidroponik/. Diakses pada tanggal 15 Juni 2012.

Hidayat, M. 2009. Sistem Hidroponik dengan Nutrisi dan Media Tanam Berbeda terhadap Pertumbuhan dan Hasil Selada. Media Litbang Sulteng 2(2):131-136.

Jones, J. B. 2005. Hydroponics. CRC PRESS. United States of America. $423 \mathrm{hlm}$.

Morgan, L. 2000. Are Your Plants Suffocating? The Importance of Oxygen in Hydroponics. The Growing Edge 12(6):50-54. 
Nathania, B., I.M. Sukewijaya, dan N.W.S. Sutari. 2012. Pengaruh Aplikasi Biourin Gajah terhadap Pertumbuhan dan Hasil Tanaman Sawi Hijau. EJurnal Agroekoteknologi Tropika 1(1):23016515.

Nyakpa, M. Yusuf, A. M. Lubis, M. A. Pulung, G. Amrah, A. Munawar, G. B. Hong, dan N. Hakim. 1988. Kesuburan Tanah. Universitas Lampung. Bandar Lampung. $258 \mathrm{hlm}$.

Republika Online. 2010. Konsumsi Sayuran Rakyat Indonesia Masih Rendah. http:// www.republika.co.id/berita/breaking-news/ nasional/10/06/14/119729-konsumsi-sayuranrakyat-indonesia-masih-rendah. Diakses pada tanggal 15 Juni 2012.
Susila, A.D. 2009. Teknologi Hidroponik SIstem Terapung (THST) Untuk Menghasilkan Sayuran Berkualitas. Departemen Agronomi dan Hortikultura, Fakultas Pertanian, IPB. Bogor. $20 \mathrm{hlm}$.

Suyitno. 2006. Respirasi pada tumbuhan. Materi disampaikan pada kegiatan pembinaan Tim Olimpiade Biologi SMAN Kalasan, Yogyakarta pada 27 Februari 2006 di SMAN Kalasan. 